\title{
Kemampuan Fusan F1 Dalam Memproduksi Inulinase
}

\author{
Wijanarka $^{1)}$; Endang Sutariningsih Soetarto ${ }^{2)}$; Kumala Dewi ${ }^{3)}$ dan Ari Indrianto ${ }^{4)}$ \\ 1) Lab. Mikrobiologi_FSM (MIPA) Undip, Tembalang Semarang 50275 \\ 2) Lab. Mikrobiologi__ F Biologi UGM, Bulaksumur Jogyakarta 55281 \\ ${ }^{3)}$ Lab. Fisiologi Tumbuhan _ F Biologi UGM, Bulaksumur Jogyakarta 55281 \\ 4) Lab. Bioteknologi _ F Biologi UGM, Bulaksumur Jogyakarta 55281 \\ Email : wikasmara@yahoo.co.id. HP. 08179526187
}

\begin{abstract}
Fusan F1 was the result of the fusion of the Pichia manshurica and Rhodosporidium paludigenum. The second type of yeast has the ability to produce inulinase. Inulinase (EC. 3.2.1.7) is an enzyme that is classified as a hydrolase enzyme, this enzyme has the ability to break down complex inulin into simpler components that fructose. Fructose was a monosaccharide with huge potential for the manufacture of butanol, iOS, pullan, FOS and ethanol. The purpose of research to determine the ability fusan F1 in producing inulinase and to determine the specific growth rate ( ), as well as the generation time $(\mathrm{g})$ fusan F1.The results showed that fusan F1 at the $18{ }^{\text {th }}$ hour was able to produce inulinase of $0.61 \mathrm{~mol} / \mathrm{min}$. These results are higher than the parental namely $P$. manshurica ( 0.56 $\mathrm{mol} / \mathrm{min})$ and $R$. paludigenum $(0.33 \mathrm{~mol} / \mathrm{min})$. While The specific growth rate ( ) and generation time (g) fusan $\mathrm{F} 1$ respecly $0.25 \mathrm{~h}$ and $2.7 / \mathrm{h}$.
\end{abstract}

Keywords: Fusan F1; inulinase; the specific growth; generation time

\begin{abstract}
Abstrak
Fusan F1 merupakan hasil fusi dari Pichia manshurica dan Rhodosporidium paludigenum. Kedua jenis khamir tersebut mempunyai kemampuan menghasilkan inulinase. Inulinase (E.C.3.2.1.7) merupakan enzim yang tergolong sebagai enzim hidrolase, enzim ini mempunyai kemampuan untuk memecah komplek inulin menjadi komponen yang lebih sederhana yaitu fruktosa. Fruktosa merupakan suatu monosakarida yang sangat potensial untuk pembuatan butanol, IOS, pullan, FOS dan ethanol. Tujuan penelitian untuk mengetahui kemampuan fusan F1 dalam memproduksi inulinase dan untuk mengetahui kecepatan pertumbuhan specific $(\mu)$, serta waktu generasi $(\mathrm{g})$ fusan F1. Hasil penelitian menunjukkan bahwa fusan F1 pada jam ke-18 mampu menghasilkan inulinase sebesar $0.61 \mu \mathrm{mol} / \mathrm{menit}$. Hasil tersebut lebih tinggi dibanding dengan parentalnya yaitu $P$. manshurica $(0.56 \mu \mathrm{mol} / \mathrm{menit})$ dan $R$. paludigenum $(0.33 \mu \mathrm{mol} / \mathrm{menit})$. Sedangkan kecepatan pertumbuhan specifik $(\mu)$ dan waktu generasi $(\mathrm{g})$ fusan F1 masing-masing sebesar 0.25 jam dan dengan 2.7/ jam.
\end{abstract}

Kata kunci : Fusan F1; inulinase; pertumbuhan specifik; waktu generasi

\section{PENDAHULUAN}

Tanaman dahlia merupakan tanaman perdu setinggi $1,5 \mathrm{~m}$ atau lebih dan berumbi besar. Bentuk umbi akar dahlia bervariasi mulai dari bulat kecil sampai besar atau panjang sampai lonjong. Struktur umbi dahlia terdiri atas kulit umbi yang berwarna putih kekuning-kuningan sampai kecoklatan, daging umbi tebal berwarna putih atau bening dan mempunyai mata tunas. Setiap 100 gram umbi dahlia mengandung inulin $65,7 \%$, abu $4,5 \%$, protein $3,71 \%$, air $2,97 \%$ dan bahan lainnya 23,10\% (Rukmana, 2000). Menurut Byun \& Nahm (1978), total persentase gula sebagai fruktosa dalam inulin bervariasi dari 7598\% tergantung pada pertumbuhan dan kondisi penyimpanan setelah panen.

Inulin merupakan polifruktan yaitu polimer fruktosa rantai linier dengan ikatan $\beta-2,1$ fruktofruktanosidik dengan satu unit terminal glukosa di ujung (Byun \& Nahm, 1978), dengan panjang rantai polisakarida ini kurang lebih 25-35 unit fruktosa (Allais et al., 1986). Inulin terdiri 
dari atas molekul fruktosa yang terpolimerisasi dan terdapat sebagai cadangan makanan pada sejumlah tumbuhan seperti Compositae (misal umbi dahlia). Inulin tidak dapat larut dalam air dingin tetapi suhu $50^{\circ} \mathrm{C}$ dapat melarutkan $50 \%$ inulin (Vandamme \& Derycke, 1983).

Struktur umbi dahlia terdiri atas kulit umbi berwarna putih kekuning-kuningan sampai kecoklatan, daging umbi tebal baerwarna putih atau bening dan mempunyai mata tunas. Satu rumpun tanaman dahlia dapat menghasilkan umbi sebanyak $2-5 \mathrm{~kg}$, tergantung pada varietas dan kesuburan tanaman. Umbi dahlia mengandung $80 \%$ air dan $20 \%$ padatan. Padatan ini tersusun oleh kira-kira $65 \%$ inulin; abu $4,5 \%$; protein $3,71 \%$; air 2,97\%; dan bahan lainnya $23,10 \%$ (Rukmana, 2000). Semakin tua umur umbi dahlia, maka kandungan inulin dalam umbi tersebut juga semakin banyak. Kemampuan enzim yang mampu merombak inulin menjadi unit sederhana fruktosa dikenal dengan nama inulinase.

Inulinase (E.C.3.2.1.7.) merupakan enzim hidrolase yang digolongkan sebagai 2,1- $\beta$-Dfructan-fructanohydrolase yang mampu menghidrolisis molekul inulin menjadi sejumlah besar fruktosa dan sedikit glukosa dengan memotong unit fruktosa dari molekul inulin pada posisi terminal $\beta-2,1$ (Rouwenhorst et al., 1990; Park \& Yun, 2000). Inulinase terdapat secara alami pada umbi tanaman yang mengandung inulin (misal: umbi dahlia) atau pada mikroorganisme seperti dari golongan jamur: Aspergillus sp, Penicillium sp, Chrysosporium sp, golongan khamir: Kluyveromyces sp, Candida sp, Debaryomyces sp, Saccharomyces sp, dan dari golongan bakteri: Arthrobacter sp, Flavobacterium sp, dan Bacillus sp.

Berdasarkan tempat aktivitasnya, inulinase dapat dibedakan menjadi dua, yaitu eksoinulinase dan endoinulinase. Eksoinulinase ( $\beta$-Dfruktanfruktohidrolase, EC 3.2.1.80) memecah inulin dari ujung non reduktif, sedangkan endoinulinase (2,1- $\beta$-D-fruktan fruktanohydrolase, EC 3.2.1.7) memecah inulin secara acak dari bagian dalam untuk menghasilkan fruktooligosakarida seperti inulotriosa, tetraosa, dan pentaosa sebagai produk utamanya. Sampai saat ini sifat eksoinulinase lebih banyak diketahui dari pada sifat endoinulinase (Allais et al., 1986).
Enzim adalah biokatalis yang dalam jumlah sedikit mempunyai kemampuan untuk mempercepat berlangsungnya reaksi kimiawi dan enzim tersebut tak mengalami perubahan bentuk. Katalis ini bersifat spesifik, artinya suatu katalis tetentu akan berfungsi pada suatu jenis reaksi tertentu saja.

Enzim sebagai produk sel hanya dapat disintesis jika sel mempunyai gen untuk enzim tersebut (Sadikin, 2002). Suatu organisme harus mempunyai gen struktural untuk menentukan sintesis struktur enzim dalam hal urutan asamasam aminonya, yang diperlukan untuk kehidupannya.

Inulin merupakan polisakarida yang dibangun oleh unit-unit monomer fruktosa melalui ikatan $\beta$-2-1-fruktofuranosida yang diawali oleh satu molekul glukosa. Karbohidrat ini dihasilkan oleh tanaman jenis compositae seperti Chicory, Jerusalem artichoke dan dahlia. Polifruktosa dengan derajat polimerisasi 30 keatas disebut dengan inulin (Nakamura et al., 1995). Inulin tidak dapat larut dalam air dingin tetapi suhu $50^{\circ} \mathrm{C}$ dapat melarutkan $50 \%$ inulin. Molekul ini dapat mengendap dalam campuran etanol-air (Vandamme dan Derycke, 1983). Total persentase gula sebagai fruktosa dalam inulin bervariasi dari 75-95\% tergantung pada pertumbuhan dan kondisi penyimpanan setelah dipanen (Byun \& Nahm, 1978).

Hidrolisis inulin menjadi fruktosa dapat dilakukan pada kondisi asam pada $\mathrm{pH}$ 1-2 dengan suhu $80^{\circ} \mathrm{C}-100^{\circ} \mathrm{C}$, namun hasil yang diperoleh berkualitas rendah karena akan terbentuk fraksi yang berwarna gelap dan hasil samping yang tak diinginkan seperti difruktosa anhidrat (Allais et al., 1986; Xiao et al., 1988). Hidrolisis menggunakan enzim inulinase dapat menghindari adanya kerugian tersebut. Produksi fruktosa dari bahan berpati lainnya memerlukan 3 macam enzim yaitu amylase, amilogluksidase, dan glukosa isomerase.

Fusan F1 merupakan fusan hasil fusi dari Pichia manshurica dan Rhodosporidium paludigenum . Kedua jenis khamir tersebut merupakan bioresources dari tanaman bunga Dahlia dan mempunyai sifat sebagai khamir inulinolitik. Namun demikian kedua jenis khamir tersebut hanya mampu memproduksi enzim inulinase dalam jumlah yang kecil. Sehingga 
dengan demikian perlu diupayakan untuk mencari sumber enzim (mikrobia, fusan) yang mampu meningkatkan produksi inulinase. Salah satu upaya untuk meningkatkan produksi enzim tersebut dengan cara fusi protoplas. Metode fusi protopas dipilih karena tidak memerlukan vector, mudah dan tidak memerlukan sel yang kompeten.

\section{BAHAN DAN METODE}

\section{Mikroorganisme}

Sumber mikroba yang digunakan pada penelitian ini adalah kultur murni fusan F1 yang merupakan hasil fusi dari Pichia manshurica dan Rhodosporidium paludigenum.

\section{Kultivikasi medium dan produksi inulinase}

Media untuk pemeliharaan kultur dan produksi inulinase menurut Erthan $(2003)(\mathrm{g} / \mathrm{L})$ : inulin-30; $\quad \mathrm{NH}_{4} \mathrm{NO}_{3}-2.3 ; \quad\left(\mathrm{NH}_{4}\right)_{2} \mathrm{HPO}_{4}-3.7$; $\mathrm{K}_{2} \mathrm{HPO}_{4}-1 ; \mathrm{MgSO}_{4} \cdot 7 \mathrm{H}_{2} \mathrm{O}-0.5 ;$ yeast ekstrak-1.5 dan $\mathrm{pH}$ 5. Medium di autoklaf pada suhu $121^{\circ} \mathrm{C}$ selama 20 menit. Setelah diinokulasi, Erlenmeyer di rotary shaker pada suhu $28^{\circ} \mathrm{C}$ dengan kecepatan $150 \mathrm{rpm}$.

\section{Enzyme assay}

Sebanyak $0,1 \mathrm{ml}$ larutan enzim dicampur dengan subtrat inulin $0,1 \%$ dalam larutan bufer sodium asetat $\mathrm{pH}$ 5. Selanjutnya diinkubasi selama 30 menit pada suhu $50^{\circ} \mathrm{C}$. Gula reduksi yang terbentuk ditentukan dengan metode DNS (Chaplin, 1994; Park, J.P and J.W. Yun. 2001). Aktivitas inulinase ditentukan berdasarkan sejumlah enzim yang mampu merombak $1 \mu \mathrm{mol}$ substrat permenit pada kondisi tertentu.

\section{HASIL DAN PEMBAHASAN}

1. Pertumbuhan dan inulinase Fusan F1

Pertumbuhan populasi suatu mikroorganisme merupakan akibat dari pertumbuhan sel secara individu. Pertumbuhan tersebut biasanya ditunjukkan dengan adanya pertambahan jumlah sel atau masa sel yang sedang tumbuh. Pertumbuhan mikroorganisme dipengaruhi oleh faktor lingkungan atau genetik.

Fusan F1 merupakan khamir yang tumbuh dalam medium pertumbuhan dengan inulin sebagai satu-satunya sumber karbon dengan $\mathrm{pH} 5$. Pertumbuhan fusan F1 dilakukan selama 48 jam dan dilakukan pengamatan setiap 6 jam. Fusan ini merupakan fusan yang diperoleh dari fusi dari Pichia manshurica dan Rhodosporidium paludigenum. Kedua jenis khamir tersebut merupakan bioresources mikroorganisme dari tanaman bunga Dahlia (Lunggani dkk., 2009).

Dari hasil penelitian menunjukan bahwa pertumbuhan fusan F1, terjadi fase log setelah waktu inkubasi anatara $t_{0}$ sampai $t_{18}$ (Gambar 1 ). Fase log yang terjadi pada jam tersebut yang demikian singkat diakibatkan adanya pemberian starter. Adanya starter ini mengakibatkan fase lag (fase adaptasi) hilang atau diperpendek sehingga mengakibatkan lebih cepat memasuki fase logaritmik.

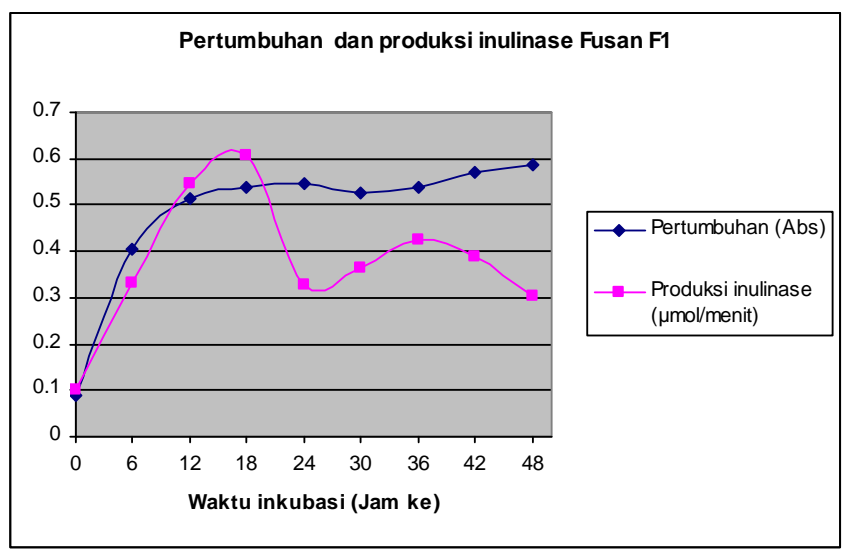

Gambar1. Pertumbuhan fusan F1 


\section{Produksi inulinase}

Produksi inulinase oleh fusan F1 dilakukan dengan menumbuhkan fusan tersebut kedalam medium produksi cair. Inulinase merupakan enzim ekstraseluler yang disekresikan keluar sel bercampur dengan medium produksi, sehingga di dalam proses penghitungan produksi enzim diukur melalui supernatan hasil sentrifugasi medium. Jumlah inulinase yang diproduksi dapat ditentukan dengan uji aktivitas enzim (Sadikin, 2002).

Tabel 1. Produksi inulinase fusan F1

\begin{tabular}{ccc}
\hline $\begin{array}{c}\text { Waktu } \\
\text { inkubasi (Jam } \\
\text { ke-) }\end{array}$ & $\begin{array}{c}\text { Pertumbuhan } \\
(\text { Abs })\end{array}$ & $\begin{array}{c}\text { Produksi inulinase } \\
(\mu \text { mol/menit })\end{array}$ \\
\hline 0 & 0.0883 & 0.1009 \\
\hline 6 & 0.4045 & 0.3306 \\
\hline 12 & 0.5129 & 0.5470 \\
\hline 18 & 0.5379 & 0.6088 \\
\hline 24 & 0.5469 & 0.3261 \\
\hline 30 & 0.5272 & 0.3649 \\
\hline 36 & 0.5391 & 0.4249 \\
\hline 42 & 0.5686 & 0.3885 \\
\hline 48 & 0.5884 & 0.3024 \\
\hline
\end{tabular}

Adanya inulin dalam medium produksi cair dapat menginduksi proses pembentukan enzim inulinase oleh fusan F1. Sehingga dengan demikian proses pembentukan enzim inulinase dapat digolongkan sebagai enzim induktif. Hal ini sesuai dengan Xiao et al. (1988) bahwa inulin merupakan induser dalam sintesis inulinase dan, bersifat adaptif. Inulinase disintesis selama terjadi pertumbuhan khamir dan mencapai maksimum pada fase stasioner (Byun \& Nahm, 1978). Inulinase yang terdapat pada kultur cair disebut sebagai inulinase supernatan (Rouwenhorst ${ }^{\mathrm{b}}$ et al., 1990) dan bersifat termotoleran (Park et al., 2001). Inulinase merupakan hasil dari metabolit primer dan bersifat growth asosiated.

Tabel 2. Kecepatan pertumbuhan specifik ( ) dan waktu generasi (g) serta produksi inulinase fusan F1

\begin{tabular}{cccc}
\hline Strain & Pertumbuhan specifik ( ) & Waktu generasi (g) & $\begin{array}{c}\text { Produksi inulinase } \\
(\mu \text { mol/menit })\end{array}$ \\
\hline F1 & 0.2536 & 2.7334 & 0.608 \\
\hline P. manshurica & 0.2794 & 2.4815 & 0.557 \\
\hline Rh. paludigenum & 0.3787 & 1.8304 & 0.326 \\
\hline
\end{tabular}

Pada tahap ini dilakukan pengukuran kecepatan pertumbuhan specific $(\mu)$ dan waktu generasi. Berdasarkan Tabel 2 terlihat bahwa fusan F1 mampu menghasilkan produksi inulinase lebih tinggi dari pada kedua parentalnya yaitu $\mathrm{P}$. manshurica dan Rh. paludigenum. Hal ini diduga karena adanya proses akumulatif dari kedua induknya, sehingga mengakibatkan produksi inulin meningkat.

\section{KESIMPULAN}

Berdasarkan penelitian yang telah dilakukan dapat disimpulkan bahwa Fusan F4 mampu menghasilkan produksi inulinase sebesar 0.60882 $\mu \mathrm{mol} / \mathrm{menit}$ dengan kecepatan pertumbuhan 
specific $(\mu)$ sebesar 0.2536 jam dengan waktu generasi (g) 2.7334 jam.

\section{DAFTAR PUSTAKA}

Allais, J.J. S. Kammoun,. P. Blanc,. C. Girard and J. Baratti. 1986. Isolation and Characteristic of Bacterial Strains with Inulinase Activity. Appl. Environ. Microbiol. 52 (5) : 10861090.

Byun, S. M. dan B.H. Nahm. 1978. Production of Fructose from Jerusalem artichoke by Enzymatic Hydrolisis. J. of Food science. 43 : 1871-1873.

Chaplin, M.F dan J.F. Kennedy. 1994. Cahbohydrat Analysis: A Practical Approach. $2^{\text {nd }}$ Edition. Oxford University Press. Oxford.

Ertan, F., T. Aktac, A. C. Kaboglu, F. Ekinci and E. Bakar. 2003. Determination of Optimum Cultivation Condition on The Production of Inulinase from Rhizoctonia solani. Pak. J. Bi.l. Sci.6 (16): 1386-1388.

Lunggani, A.T; Wijanarka dan Endang K., 2009. Produksi IOS Prebiotik Berbasis Pemanfaatan Umbi Dahlia (Dahlia variabilis) Oleh Khamir Inulinolitik Dan Pengujian Antimikrobanya Secara Invitro. Penelitian Hibah Multiyears Desentralisasi.

Nakamura, T., Y. Ogata, A. Shitasa, A. Nakamura dan K. Ohta. 1995. Continuous Production of Fructose Syrups from Inulin by Immobilized Inulinase from Aspergillus niger Mutan 817. Journal of Fermentation and Bioeng. 80(2) : 164-169. et al, 1995).
Park, J.P and J.W. Yun. 2001.Utilization of Chicory roots for Microbial Endoinulinase Production.Letters In Applied Microbiology. 2001 (33): 183 - 187

Pelczar. M.J. and Chan E.C.S. 1986. Dasar-Dasar Mikrobiologi. Terjemahan: Ratna Siri H, T. Imas, S.S. Tjitrosomo, dan Sri Lestari Angka. UI press, Jakarta

Rukmana, R. 2000. Dahlia: Prospek Agribisnis dan Teknik Budi Daya. Penerbit Kanisius. Yogyakarta.

Rouwenhorst $^{\mathrm{b}}$, R.J., M. Hensing, J. Verbakel, W.A Scheffers \& J.P.V. Dijken. 1990. Structure \& Properties of The Extracellular Inulinase of Kluyveromyces marxianus. Jounal Appl. \& Envir. Microbiology. The Netherlands. p: 3337-3345.

Sadikin, M. 2002. Seri Biokimia: Biokimia Enzim. Penerbit Widya Medika. Jakarta.

Vandamme, E. J. and D.G. Derycke. 1983. Microbial Inulinases: Fermentation Process, Properties and Applications. Advances in Appl. Microbiol. 29: 139-176.

Wijanarka, Endang K. dan Hermin P. 2006a. Paket Teknologi Eksplorasi Khamir Inulinolitik Termostabil Umbi Dahlia (Dahlia variabilis Willd.) Jawa Tengah Melalui Teknik Fusi Protoplas dan Aplikasinya pada Produksi High Fructose Syrup (HFS). Laporan HB PT XIV/1. Undip. Semarang

Xiao, R., M. Tanida dan S. Takao.1988. Innulinase from Crysosporium pannorum. J. Fement. Technol. 66 (5) : $244-248$. 